\title{
Structural and magnetic properties of mechanochemically synthesized nanocrystalline titanium monoxide
}

\author{
Tanja Barudžija ${ }^{1}$, Alexey A. Gusev ${ }^{2}$, Dragana Jugović ${ }^{3}$, Miroslav Dramićanin ${ }^{1}$, Miodrag Zdujić ${ }^{3}$, \\ Čedomir Jovalekić ${ }^{4}$ Miodrag Mitrić ${ }^{1}$ \\ ${ }^{1}$ University of Belgrade, Institute for Nuclear Sciences "Vinča", Belgrade, Serbia \\ ${ }^{2}$ Institute of Solid State Chemistry and Mechanochemistry, The Siberian Branch of the Russian Academy of Sciences, \\ Novosibirsk, Russia \\ ${ }^{3}$ Institute of Technical Sciences of the Serbian Academy of Sciences and Arts, Belgrade, Serbia \\ ${ }^{4}$ University of Belgrade, Institute for Multidisciplinary Research, Belgrade, Serbia
}

\begin{abstract}
Nano-sized titanium monoxide ( $\mathrm{TiO}$ ) powder was prepared by mechanochemical synthesis. A mixture of commercial $\mathrm{Ti}$ and $\mathrm{TiO}_{2}$ (rutile) powders with the molar ratio of 1:1 was milled in a planetary ball mill for 5, 10, 20, 30 and 60 min under argon atmosphere. The final single-phase titanium monoxide sample was characterized by X-ray diffraction (XRD), magnetic measurements using a superconducting quantum interference device magnetometer (SQUID) and thermogravimetric analysis (TGA). The temperature dependency of the magnetic susceptibility is characterized by significant contribution of Pauli paramagnetism due to conduction electrons.
\end{abstract}

SCIENTIFIC PAPER

UDC 661.882:544:62

Hem. Ind. 66 (2) 181-186 (2012)

doi: 10.2298/HEMIND111027090B

Keywords: titanium monoxide, mechanochemical synthesis, nanomaterials, Rietveld method, magnetic measurements.

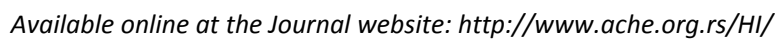

Titanium monoxide belongs to the class of strongly nonstoichiometric compounds with a broad homogeneity region that contains very large concentration of vacancies in both the metal and oxygen sublattices [1]. Titanium monoxide crystallizes in the cubic structure ( $\mathrm{NaCl}$ structure type) with compositions ranging from $\mathrm{TiO}_{0.70}$ to $\mathrm{TiO}_{1.25}$, and simultaneously contains $10-15$ at.\% structural vacancies [2]. $\mathrm{TiO}_{0.70}$ composition has a titanium sublattice that is almost completely occupied with about one-third of the oxygen sites being vacant, while $\mathrm{TiO}_{1.25}$ composition has oxygen lattice almost filled with about one-quarter of the titanium sites being vacant [3]. Depending on the oxygen content and heat treatment, the distribution of vacancies can be disordered or ordered [4]. This results in two different polymorphs of $\mathrm{TiO}_{y}$, both closely related to the cubic structure: the first being in the disordered cubic phase atoms with vacancies that are randomly distributed, and the second with the low-temperature polymorph that has the monoclinic symmetry and ordered distribution of vacancies [5]. Using the conventional methods for the synthesis of the titanium monoxide samples leaves them, almost without an exception, in a two-phase state containing both disordered and ordered phases at the same time [6]. The preparation of the single-phase

Correspondence: M. Mitrić, Institute for Nuclear Sciences "Vinča", P.O. Box 522, 11001 Belgrade, Serbia.

E-mail:mmitric@vinca.rs

Paper received: 27 October, 2011

Paper accepted: 7 November, 2011 disordered samples of $\mathrm{TiO}_{y}$ requires a special quenching procedure [4].

The $\mathrm{TiO}_{y}$ monoxide can behave either like a $d$ metal or like a semiconductor, depending on the oxygen content [6]. The metal-semiconductor transition is experimentally observed with an increase in the oxygen content in disordered titanium monoxide $\mathrm{TiO}_{y}$, i.e., with a decrease in the concentration of oxygen vacancies and a simultaneous increase in the concentration of titanium vacancies [6]. Titanium monoxide, having low electrical resistivity and good barrier property against the interdiffusion of $\mathrm{Al}$ and $\mathrm{Si}$, could be considered as an electrically conducting metallic layer for application in microelectronics layered structures $[7,8]$.

TiO bulk samples can be prepared by various methods such as: the reduction of $\mathrm{TiO}_{2}$ with metallic titanium [9], the arc-melting with annealing in argon afterwards [10], the melt quenching of $\mathrm{Ti}$ and $\mathrm{TiO}_{2}$ mixture using an arc furnace under argon atmosphere [11], the solid-state reactions with subsequent annealing in evacuated quartz tubes followed by quenching [4]. It was also demonstrated that titanium monoxide could be obtained by mechanochemical tretment of $\mathrm{TiO}_{2}$ and $\mathrm{Ti}$ stoichiometric powder mixture either in argon $[12,13]$ or air atmosphere [14].

In this work, we present the properties of nanocrystalline titanium monoxide synthesized by mechanochemical reaction between $\mathrm{Ti}$ and $\mathrm{TiO}_{2}$. The obtained sample was, in detail, characterized by X-ray diffraction (XRD) analysis, thermal gravimetric/differential thermal analysis (TGA/DTA) and the magnetic measurements. 
For the first time, crystal structure refinement for nanocrystalline titanium monoxide was done. In addition, the field and temperature dependency of magnetic susceptibility and magnetization were experimentally studied.

\section{EXPERIMENTAL}

A mixture of commercial titanium sponge (Johnson, Matthey \& Co., Limited) and $\mathrm{TiO}_{2}$ (rutile, Alfa Aesar) powders with a molar ratio of 1:1 was used as the starting material. Mechanochemical treatment was carried out under argon atmosphere using a Fritsch Pulverisette 7 Premium Line planetary micro mill, with tungsten carbide vials of $45 \mathrm{ml}$ volume filled with 144 tungsten carbide balls of $5 \mathrm{~mm}$ diameter. The mass of the powder was $7 \mathrm{~g}$, hence the balls to powder mass ratio was 20:1. The angular velocities of the supporting disc and vial were 104.7 (1000 rpm) and $209.4 \mathrm{rad} \mathrm{s}^{-1}$ (2000 $\mathrm{rpm})$, respectively. After the selected milling times (5, $10,20,30$ and $60 \mathrm{~min}$ ), an amount of powder was taken for X-ray diffraction analysis. The XRD measurements were done on a Philips PW 1050 powder diffractometer with $\mathrm{Ni}$ filtered CuK $\alpha$ radiation $(\lambda=1.5418$ $\AA)$ and scintillation detector within $25-85^{\circ} 2 \theta$ range in steps of $0.05^{\circ}$, with the scanning time of 3 s per step. After the XRD measurements, the powder was returned in a vial in order to keep the same balls to powder mass ratio throughout the milling. For Rietveld refinement, the XRD measurements were done within $25-135^{\circ} 2 \theta$ range in steps of $0.02^{\circ}$, and scanning time of $14 \mathrm{~s}$ per step.
The simultaneous TGA/DTA measurements were carried out up to $900{ }^{\circ} \mathrm{C}$ in air atmosphere at a heating rate of $20^{\circ} \mathrm{C} \mathrm{min}^{-1}$ using a TA SDT Model 2090 thermobalance.

The magnetic measurements were done using a superconducting quantum interface device (Quantum Design MPMS SQUID magnetometer). Zero field cooled (ZFC) measurements were carried out in the temperature range of 2-300 $\mathrm{K}$ in the applied field of 100 Oe. The measured magnetic susceptibility data were corrected for the temperature independent diamagnetic susceptibility, using gram ionic susceptibility values given by Selwood [15]. The field dependency of the isothermal magnetization $M$ was recorded in the magnetic fields between -50 and $50 \mathrm{kOe}$ and at a temperature of $4 \mathrm{~K}$.

\section{RESULTS AND DISCUSSION}

\section{Mechanochemical synthesis and structural properties}

Figure 1 shows the XRD patterns of $\mathrm{Ti}$ and $\mathrm{TiO}_{2}$ (rutile) equimolar mixture milled for various periods. In the early stage of milling (within $5 \mathrm{~min}$ ), the peaks of a new phase can be detected in the patterns, although the peaks of the starting materials $\mathrm{Ti}$ and $\mathrm{TiO}_{2}$ remain. The new peaks are identified as cubic titanium monoxide. As the milling time increases, the peak intensities of titanium monoxide increased, while the peaks of the starting reactants decreased. After $60 \mathrm{~min}$, the reaction was completed and all broad peaks may be assigned to the nanocrystalline titanium monoxide.

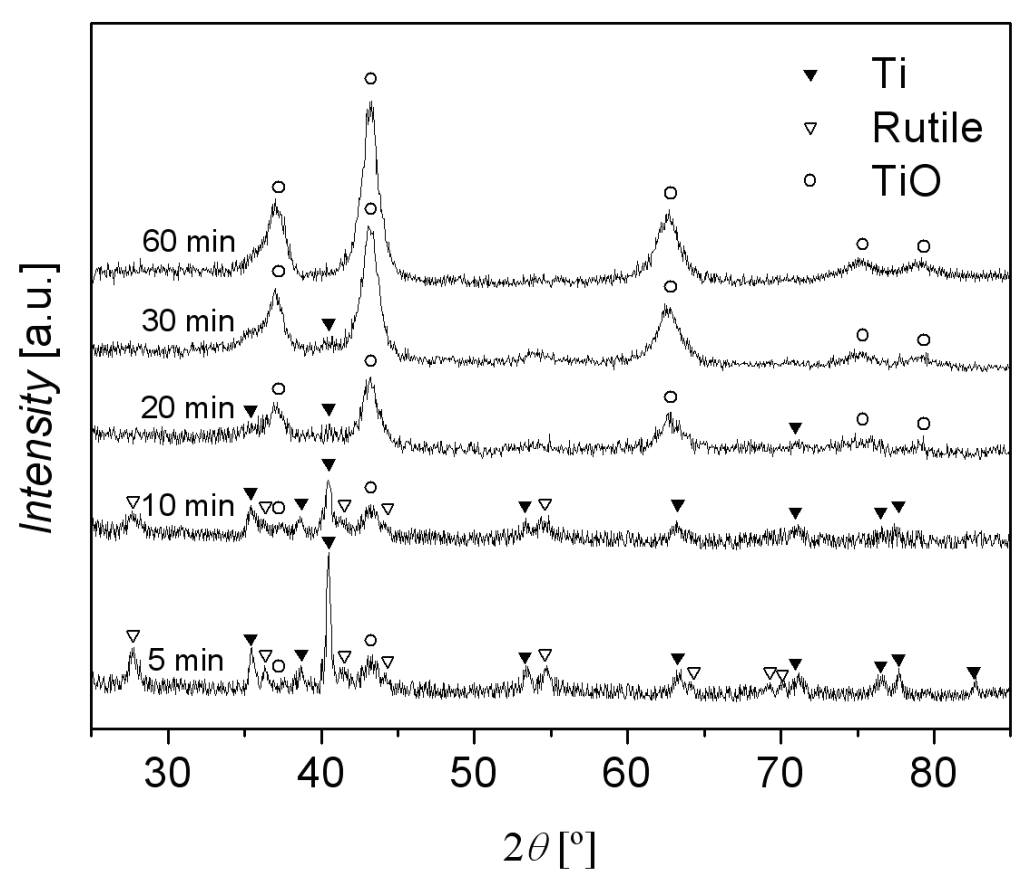

Figure 1. XRD patterns of the mixture of $\mathrm{Ti}_{\text {and }} \mathrm{TiO}_{2}$ powders with molar ratio of 1:1 milled for 5, 10, 20, 30 and $60 \mathrm{~min}$. 
The TGA/DTA measurements (Figure 2) were used to determine $\mathrm{Ti}: \mathrm{O}$ ratio from the mass increase during the oxidation to $\mathrm{TiO}_{2}$, hence calculated composition of mechanochemically synthesized titanium monoxide is $\mathrm{TiO}_{1.03}$.

Titanium monoxide with disordered distribution of vacancies crystallizes in the cubic $\mathrm{NaCl}$ structure type (S.G. $F m \overline{3} m$ ). In this structure, titanium occupies special crystallographic position $4 a[0,0,0]$ while oxygen is placed in special crystallographic position $4 b[1 / 2,1 / 2,1 / 2]$, both with the same local symmetry $\mathrm{m} 3 \mathrm{~m}$. The lowtemperature $\mathrm{TiO}_{y}$ phase with an ordered distribution of vacancies, stable between the approximate compositions $y=0.9$ and 1.1 below $1000^{\circ} \mathrm{C}$, has the monoclinic symmetry (S.G. A2/m). The vacancies are ordered within every third (100) plane [9]. In these planes, one site per two is vacant, which results in the theoretical concentration of $16.6 \%$ of vacancies and $A_{5} B$ stoichiometry for each sublattice $\left(\mathrm{Ti}_{5} \square ; \mathrm{O}_{5} \square\right.$, where $\square$ symbolizes a vacancy).

The obtained XRD data were refined considering two possible space groups: $F m \overline{3} m$ and $A 2 / m$. The refined $R$ agreement factors of monoclinic structure were approximately equal to $R$ factors calculated for cubic structure. Thus, according to commonly accepted convention we can say that mechanochemically synthesized $\mathrm{TiO}_{1.03}$ has disordered the cubic structure (Figure 3). A few weak maxima of the tungsten carbide arising

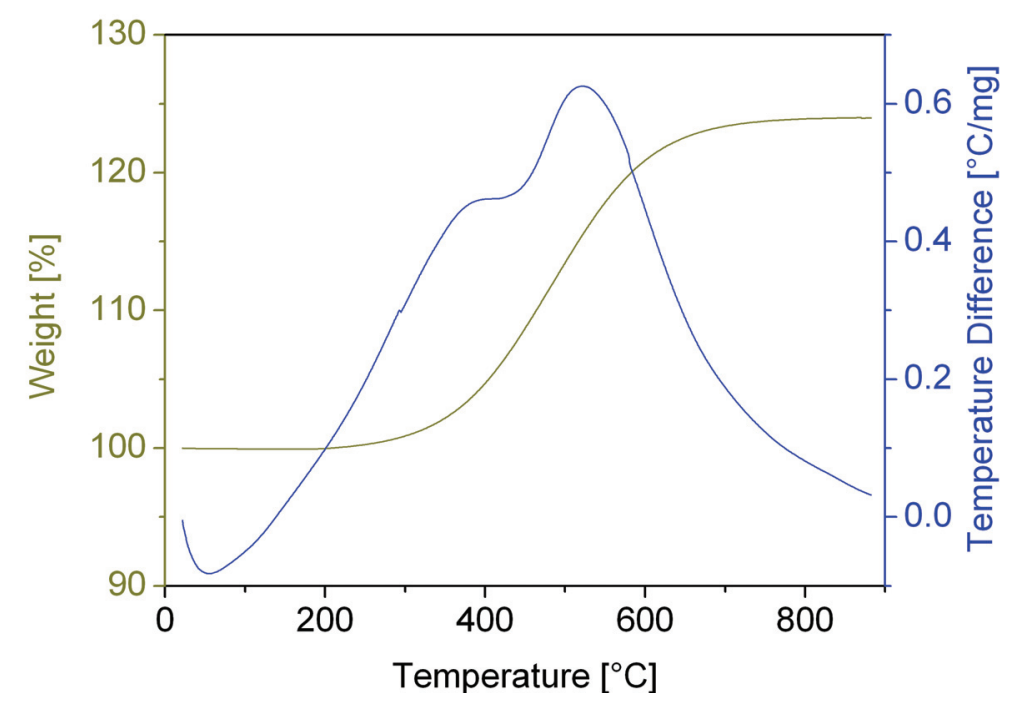

Figure 2. Simultaneous TGA/DTA measurements carried out up to $900{ }^{\circ} \mathrm{C}$ in the air atmosphere for the sample prepared by mechanochemical treatment for $2 \mathrm{~h}$.

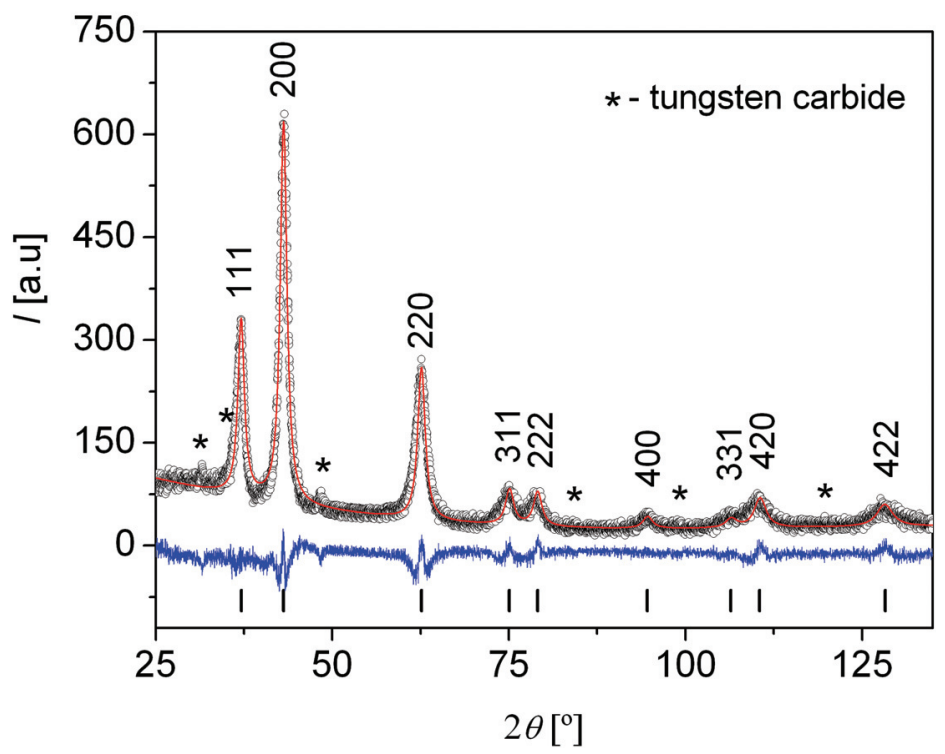

Figure 3. Final Rietveld plot of the $\mathrm{TiO}_{1.03}$ sample prepared by mechanochemical treatment for $2 \mathrm{~h}$ : observed (circles) and calculated intensities (line); the differences between the observed and calculated intensities are given by bottom solid line; the vertical bars indicate the Bragg peaks. 
from the balls and vial debris also appeared, as is usual for mechanochemically synthesized samples. The crystal structure refinement was based on the Rietveld full profile method [16] using the Koalariet computing program based on Fundamental Parameters convolution approach to generate line profiles. This program is appropriate for processing the data obtained from the samples with dominant microstructure parameters [17] The most important results of the final Rietveld refinement are presented in Table 1.

Table 1. Refined values of the cell parameter, $a$, temperature factors, $B_{T,}$ and $B_{O}$, crystallite size, microstrain and agreement factor, $R_{\text {wp }}$ for the $\mathrm{TiO}_{1.03}$ sample prepared by the mechanochemical treatment for $2 \mathrm{~h}$ (standard deviations are given in parentheses)

\begin{tabular}{lc}
\hline$a / \AA$ & $4.19360(1)$ \\
$B_{\mathrm{Ti}} / \AA$ & $1.73(5)$ \\
$B_{\mathrm{O}} / \AA$ & $0.76(8)$ \\
Crystallite size, $\AA$ & $91(2)$ \\
Microstrain, \% & $0.12(6)$ \\
$R_{\mathrm{wp}} / \%$ & 9.84 \\
\hline
\end{tabular}

In this cubic structure all fractional coordinates are fixed, thus only the cell parameter and two temperature factors of all atomic parameters remain to be refined. Because of the small number of refined parameters, it is suitable to obtain microstructural parameters (crystallite size and microstrain). Due to the nanocrystalline nature of the synthesized sample (crystallite size of $9 \mathrm{~nm}$,) the calculated cell parameter (Table 1) is larger than that of the sample prepared by solid state reaction at $1770 \mathrm{~K}$ [4] but very closed to the previously synthesized nanocrystaline $\mathrm{TiO}_{1.19}$ by ball milling $[12,14]$. The obtained values of $B$ temperature factors were within the expected range, except for the titanium temperature factor, which was somewhat larger. This can be attributed to the composition of $\mathrm{TiO}_{1.03}$, which has more titanium than oxygen vacancies. A considerable high value of microstrain (imperfection of crystal) is the consequence of the mechanochemical process (which typically accumulates lattice disordering), and the presence of a large number of vacancies.

\section{Magnetic properties}

In $3 d$ transition metal monoxides, a variety of exchange interactions are possible, depending on the structure of solid and the electronic configuration of the cations. In the oxides with rock-salt structure, antiparallel orientation of spins on neighboring cations is favored by covalent mixing of anion p-orbitals with cation d-orbitals on each site. Consequently, antiferromagnetic ordering has been observed in insulators like $\mathrm{MnO}, \mathrm{FeO}, \mathrm{CoO}, \mathrm{NiO}$, but is unlikely in the case of tita- nium monoxide whose conductivity spans from semiconducting to metallic.

In the case of TiO, d-electrons occupy a narrow band with a bandwidth $W$ still larger than the intraatomic Coulomb repulsion $U$, retaining that way the itinerant character of electrons, well described by Fermi-liquid picture [18]. Rivadulla et al. [19] calculated energy bands and density of states in gradient corrected local density approximation for TiO system. The calculations showed $d$-bands well separated from $s$-bands, with the Fermi level lying in the $t_{2 g}$ bands, which overlaps with the $\mathrm{e}_{\mathrm{g}}$-bands showing the presence of itinerant behavior of delocalized d-electrons. In addition to theoretical results, the electron paramagnetic resonance (EPR) measurements of $\mathrm{TiO}_{y}$ monoxide failed to detect the presence of uncompensated magnetic moments thus pointing to delocalization of $d$ electrons [6].

Due to the reasons stated above, the temperature dependence of the magnetic susceptibility $\chi(T)$ was fitted to the equation:

$$
\chi(T)=\chi(0)+b T^{2}+\frac{C}{T+\Delta}
$$

In the expression above, the contribution of the itinerant electrons is described by the Pauli paramagnetic term which includes both a temperature independent $\chi(0)$ as well as a temperature dependent $b T^{2}$ term. The Curie modified term is introduced due to paramagnetic behavior of $\chi(T)$ data in the low temperature region $(T<50 \mathrm{~K})$.

The fit using Eq. (1) showed good agreement with our experimentally measured susceptibility data (Figure 4). The fitting parameters are presented in Table 2.

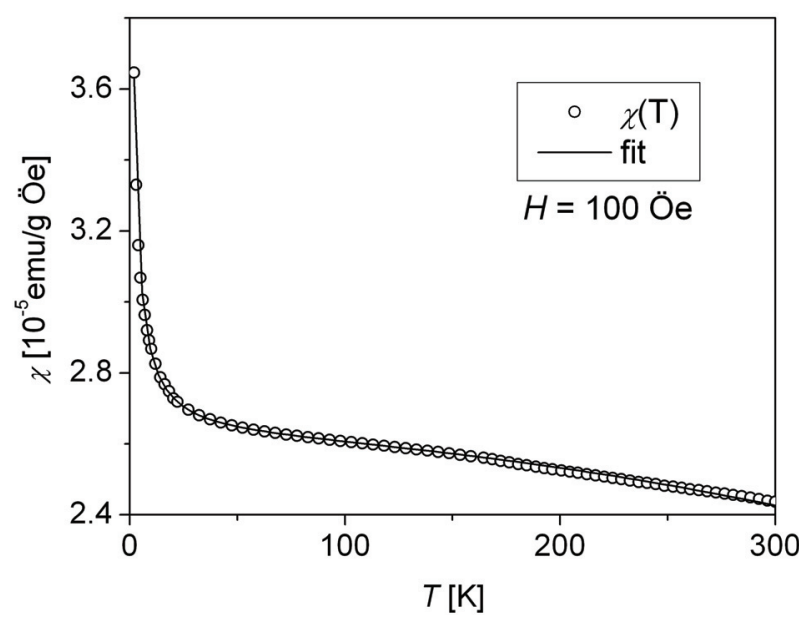

Figure 4. Magnetic susceptibility, $\chi$, within 2-300 K range in applied field of 100 Oe of $\mathrm{TiO}_{1.03}$ sample prepared by mechanochemical treatment for $2 \mathrm{~h}$.

The obtained value of the Curie constant, $C=$ $=2.71 \times 10^{-5} \mathrm{emu} / \mathrm{g}$ Oe $\mathrm{K}$, was used for the calculation of average effective magnetic moment, $\mu_{\text {eff: }}$ : 


$$
\mu_{\text {eff }} \approx \sqrt{8 C M} \mu_{\mathrm{B}}
$$

where $M$ is the molecular mass and $\mu_{\mathrm{B}}$ the Bohr magneton. The low value of the effective magnetic moment $\mu_{\mathrm{eff}} \approx 0.1 \mu_{B}$ can be attributed to the presence of $\mathrm{Ti}^{2+}$ and $\mathrm{Ti}^{3+}$ impurities. The emergence of atomic magnetic moments is a consequence of quasi-stationary electronic states localized on the crystal lattice sites [20].

Table 2. Fitting parameters of Eq. (1) on experimentally measured susceptibility data for the $\mathrm{TiO}_{1.03}$ sample prepared by the mechanichemical treatment for $2 \mathrm{~h}$ (standard deviations are given in parentheses)

\begin{tabular}{lc}
\hline$\chi(0) / 10^{-5} \mathrm{emu} \mathrm{g}^{-1}$ Oe & $2.599(2)$ \\
$C / 10^{-5} \mathrm{emu} \mathrm{g}^{-1}$ Oe K & $2.71(4)$ \\
$\Delta / \mathrm{K}$ & $0.62(4)$ \\
$b / 10^{-11} \mathrm{emu} \mathrm{g}^{-1} \mathrm{Oe} \mathrm{K}^{2}$ & $-2.02(3)$ \\
\hline
\end{tabular}

Isothermal magnetization was measured as the function of applied field between -50 and $50 \mathrm{kOe}$ at the temperature of $4 \mathrm{~K}$ (Figure 5). The measurements showed lack of remnant magnetization, which suggested the absence of ferromagnetic impurities in the system.

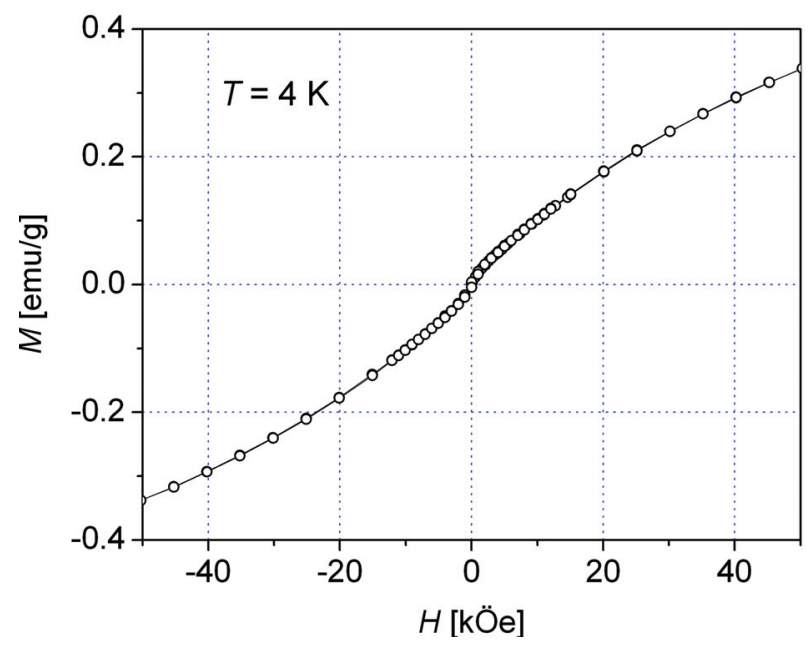

Figure 5. Magnetization, $M$, recorded in magnetic fields between -50 and $50 \mathrm{kOe}$ and at temperature of $4 \mathrm{~K}$ for the $\mathrm{TiO}_{1.03}$ sample prepared by the mechanochemical treatment for $2 \mathrm{~h}$.

\section{CONCLUSIONS}

Titanium monoxide $\mathrm{TiO}_{1.03}$ was successfully synthesized by mechanochemical treatment under argon atmosphere starting from $\mathrm{Ti}$ and $\mathrm{TiO}_{2}$ powders. Rietveld refinement of XRD data shows that this compound crystallizes in the cubic structure type, which points to disordered distribution of vacancies. The average crystallite size was determined to be $9 \mathrm{~nm}$.
The measurements of the field dependency of magnetization demonstrate that there are no ferromagnetic impurities in the system. This further proves that the observed magnetic properties are due to intrinsic magnetism of the system under investigation. The analysis of temperature dependence of the magnetic susceptibility shows the existence of two contributions:

1. Pauli paramagnetism due to itinerant delocalized d-electrons and

2. Curie modified term, which originates from the quasi-localized magnetic moments of $\mathrm{Ti}^{2+}$ and $\mathrm{Ti}^{3+}$.

\section{Acknowledgments}

This work was financially supported by the Ministry of Education and Science of the Republic of Serbia (Project Nos. 45015 and 45001).

\section{REFERENCES}

[1] R. Tetot, C. Giaconia, G. Boureau, Order and disorder in the highly defective oxides $\mathrm{TiO}_{x}, \mathrm{VO}_{x}$ and $\mathrm{NbO}_{x}$, Comp. Mater. Sci. 8 (1997) 136-141.

[2] A.A. Valeeva, A.A. Rempel', A.I. Gusev, Electrical conductivity and magnetic susceptibility of titanium monoxide, JETP Lett. 73 (2001) 621-625.

[3] C. Leung, M. Weinert, P.B. Allen, R.M. Wentzcovitch, First-principles study of titanium oxides, Phys. Rev. B $\mathbf{5 4}$ (1996) 7857-7864.

[4] A.A. Valeeva, A.A. Rempel', A.I. Gusev, Ordering of cubic titanium monoxide into monoclinic $\mathrm{Ti}_{5} \mathrm{O}_{5}$, Inorg. Mater. 37 (2001) 603-612.

[5] A.A. Valeeva, G. Tang, A.I. Gusev, A.A. Rempel', Observation of structural vacancies in titanium monoxide using transmission electron microscopy Phys. Solid State 45 (2003) 87-93.

[6] A.I. Gusev, A.A. Valeeva, The influence of imperfection of the crystal lattice on the electrokinetic and magnetic properties of disordered titanium monoxide, Phys. Solid State 45 (2003) 1242-1250.

[7] I.N. Martev, Oxygen-ion-assisted deposition of TiO films, Vacuum 58 (2000) 327-334.

[8] O. Banakh, P.E. Schmid, R. Sanjines, F. Levy, Electrical and optical properties of TiOx thin films deposited by reactive magnetron sputtering Surf. Coat. Technol. 151152 (2002) 272-275.

[9] D. Watanabe, J.R. Castles, A. Jostsons, A.S. Malin, The ordered structure of TiO, Acta Crystallogr. 23 (1967) 307-313.

[10] M.D. Banus, T.B. Reed, A.J. Strauss, Electrical and Magnetic Properties of TiO and VO, Phys. Rev., B 5 (1972) 2775-2784.

[11] S. Gokhale, S.R. Barman, D.D. Sarma, Dielectric function and optical conductivity of TiOx $(0.8<x<1.3)$ determined from electron energy-loss spectroscopy, Phys. Rev., B 52 (1995) 14526-14530.

[12] A.A. Gusev, E.G. Avvakumov, Conducting materials based on nanodispersed titanium monoxide, Sci. Sinter. 39 (2007) 295-299. 
[13] K.O. Hara, E. Yamasue, H. Okumura, K.N. Ishihara, Formation of metastable phases by high-energy ball milling in the Ti-O system, J. Phys.: Conf. Ser. 144 (2009), article 012021.

[14] I. Veljković, D. Poleti, M. Zdujić, Lj. Karanović, Č. Jovalekić, Mechanochemical synthesis of nanocrystalline titanium monoxide, Mater. Lett. 62 (2008) 2769-2771.

[15] P.W. Selwood, Magnetochemistry, Interscience, London, 1956.

[16] H.M. Rietveld, A profile refinement method for nuclear and magnetic structures, J. Appl. Cryst. 2 (1969) 65-71.
[17] R.W. Cheary, A. Coelho, A fundamental parameters approach to X-ray line-profile fitting, J. Appl. Cryst. 25 (1992) 109-121.

[18] F. Gebhard, The Mott Metal-Insulator Transition Models and Methods, Springer Tracts in Modern Physics 137, Springer, Heidelberg, 1997.

[19] F. Rivadulla, J. Fernández-Rossier, M. García-Hernández, M. A. López-Quintela, J. Rivas, J. B. Goodenough, VO: A strongly correlated metal close to a Mott-Hubbard transitionPhys. Rev., B 76 (2007) 205110.

[20] T. Moriya, Recent progress in the theory of itinerant electron magnetism, J. Magn. Magn. Mater. 14 (1979) $1-46$.

\section{IZVOD}

\section{STRUKTURNA I MAGNETNA SVOJSTVA MEHANOHEMIJSKI SINTETIZOVANOG NANOKRISTALNOG TITAN MONOKSIDA}

Tanja Barudžija ${ }^{1}$, Alexey A. Gusev ${ }^{2}$, Dragana Jugović ${ }^{3}$, Miroslav Dramićanin ${ }^{1}$, Miodrag Zdujić ${ }^{3}$, Čedomir Jovalekić $^{4}$, Miodrag Mitrić ${ }^{1}$

${ }^{1}$ Univerzitet u Beogradu, Institut za nuklearne nauke „Vinča", Beograd, Srbija

${ }^{2}$ Institut za hemiju čvrstog stanja i mehanohemiju, Sibirski ogranak Ruske akademije nauka, Novosibirsk, Rusija

${ }^{3}$ Institut tehničkih nauka Srpske akademije nauka i umetnosti, Beograd, Srbija

${ }^{4}$ Univerzitet u Beogradu, Institut za multidisciplinarna istraživanja, Beograd, Srbija

(Naučni rad)

Zbog izuzetno dobre električne provodnosti i otpornosti na koroziju, nestehiometrijske okside titana je moguće koristiti za izradu kontakata u vozilim sa velikim stepenom integrisanosti komponenti (VLSI), u računarskoj tehnici i mobilnoj telefoniji. S obzirom na ovako veliku i značajnu primenu postoji opravdan interes, kako za istraživanjima novih postupaka sinteze ovih oksida, tako i za ispitivanjima električnih i magnetnih svojstava. Titan-monoksid pripada klasi izrazito nestehiometrijskih jedinjenja, sa nehomogenim oblastima koje sadrže veliku koncentraciju vakancija kako u metalnoj tako i u kiseoničkoj podrešetki. Struktura titan-monoksida je kubna ( $\mathrm{NaCl}$ strukturni tip), a može biti sastava od $\mathrm{TiO}_{0.70}$ do $\mathrm{TiO}_{1.25} \mathrm{i}$ istovremeno da sadrži 10-15 at.\% strukturnih vakancija. Postoji više postupaka sinteze, a u ovom radu je korišćen mehanohemijski postupak. Smeša prahova Ti i $\mathrm{TiO}_{2}$ u molarnom odnosu 1:1 mlevena je u atmosferi argona. Korišćen je planetarni mlin sa volfram-karbidnim posudama i kuglama. Posle 60 min mlevenja rendgenostrukturnom analizom je utvrđeno da je sintetisan nanokristalni titan-monoksid sa srednjom veličinom kristalita od oko $9 \mathrm{~nm}$. Iz dobijenih podataka, Ritveldovom metodom je utvrđeno da jedinjenje ima kubnu kristalnu strukturu. Iz TGA/ /DTA merenja, na osnovu uvećanja mase tokom oksidacije doTiO ${ }_{2}$, određen je odnos Ti:O. Izračunat sastav mehanohemijski sintetizovanog titan monoksida je $\mathrm{TiO}_{1.03}$. Za određivanje magnetnih svojstava korišćen je SQUID magnetometar. Izotermska magnetizacija $\mathrm{TiO}_{1.03}$ uzorka merena je na temperaturi $4 \mathrm{~K} \mathrm{u}$ poljima između -50 i 50 Oe, a magnetna susceptibilnost u polju od 100 Oe i temperaturnom intervalu od 2 do $300 \mathrm{~K}$.
Ključne reči: Titan-monoksid • Mehanohemijska sinteza • Nanomaterijali • Ritveldova metoda $\bullet$ Magnetna merenja 